University of Nebraska - Lincoln

DigitalCommons@University of Nebraska - Lincoln

8-1-2007

\title{
Tillage and rotation effect on corn-soybean energy balances in eastern Nebraska
}

\author{
G.-W. Rathke \\ BASF Aktiengesellschaft, Agrarzentrum Limburgerhof, Limburgerhof, Germany \\ Brian Wienhold \\ USDA-ARS, Brian.Wienhold@ars.usda.gov \\ Wallace Wilhelm \\ University of Nebraska-Lincoln, wwilhelm1@unl.edu \\ W. Diepenbrock \\ Institute of Agronomy and Crop Science, Martin-Luther-University Halle-Wittenberg, Germany
}

Follow this and additional works at: https://digitalcommons.unl.edu/usdaarsfacpub

Part of the Agricultural Science Commons

Rathke, G.-W.; Wienhold, Brian; Wilhelm, Wallace; and Diepenbrock, W., "Tillage and rotation effect on corn-soybean energy balances in eastern Nebraska" (2007). Publications from USDA-ARS / UNL Faculty. 109.

https://digitalcommons.unl.edu/usdaarsfacpub/109

This Article is brought to you for free and open access by the U.S. Department of Agriculture: Agricultural Research Service, Lincoln, Nebraska at DigitalCommons@University of Nebraska - Lincoln. It has been accepted for inclusion in Publications from USDA-ARS / UNL Faculty by an authorized administrator of DigitalCommons@University of Nebraska - Lincoln. 


\title{
Tillage and rotation effect on corn-soybean energy balances in eastern Nebraska
}

\author{
G.-W. Rathke ${ }^{\mathrm{a}}$, B.J. Wienhold ${ }^{\mathrm{b}, *}$, W.W. Wilhelm ${ }^{\mathrm{b}}$, W. Diepenbrock ${ }^{\mathrm{c}}$ \\ ${ }^{a}$ BASF Aktiengesellschaft, Agrarzentrum Limburgerhof, E-APE/DT, Carl-Bosch-Str. 64, 67117 Limburgerhof, Germany \\ ${ }^{\mathrm{b}}$ USDA-ARS, 120 Keim Hall, East Campus, University of Nebraska, Lincoln, NE 68583-0934, USA \\ ${ }^{\mathrm{c}}$ Institute of Agronomy and Crop Science, Martin-Luther-University Halle-Wittenberg, Ludwig-Wucherer-Str. 2, \\ 06108 Halle (Saale), Germany
}

Received 22 August 2006; received in revised form 11 June 2007; accepted 28 August 2007

\begin{abstract}
Data from a field experiment conducted in eastern Nebraska over 16 years (1986-2001) were used to determine the energy balance of corn (Zea mays L.) and soybean (Glycine max L.) as affected by tillage treatments and rotation. Tillage treatments included chisel plow, tandem disk, moldboard plow, ridge-tillage, no-till and subsoil tillage. Crop sequences were continuous corn, continuous soybean, corn in a corn-soybean rotation and soybean in a soybean-corn rotation. The energy balance was assessed by comparing the parameters: energy gain (net energy output), energy intensity (energy input per unit grain equivalent, GE) and output/input ratio. Changes in plant density, crop production practices and machinery over the course of the study were taken into account in the analysis Averaged across years, the no-till treatment required lower energy input ( $\left.7.34 \mathrm{GJ} \mathrm{ha}^{-1}\right)$ than tandem disk $\left(7.65 \mathrm{GJ}\right.$ ha $\left.{ }^{-1}\right)$, ridge-till (7.69 $\mathrm{GJ} \mathrm{ha}^{-1}$ ), chisel plow (7.83 $\left.\mathrm{GJ} \mathrm{ha}^{-1}\right)$, subsoil-tillage (7.96 $\mathrm{GJ} \mathrm{ha}^{-1}$ ) and moldboard plow $\left(8.72 \mathrm{GJ}^{-1}\right)$. The energy input was lower for soybean systems than corn. Hence, the lowest energy input was required for soybean with no-tillage (5.43 GJ ha $\left.{ }^{-1}\right)$ and highest for corn systems with moldboard plow tillage $\left(10.6 \mathrm{GJ} \mathrm{ha}^{-1}\right)$. Within a rotation the tillage treatment had a small effect on energy output with energy efficiency being more strongly affected by crop rotation than by tillage method. Moldboard plow tillage maximized the energy gain while reduced tillage (ridge-till, no-till) minimized energy intensity and maximized output/input ratio. Within crops and crop rotations, the highest energy gain $\left(98 \mathrm{GJ}^{-1}\right)$ and lowest energy intensity $\left(162.4 \mathrm{GJ} \mathrm{GE}^{-1}\right)$ occurred in corn production. For both corn and soybean, the energy gain was greater for crop rotations $\left(92.8 \mathrm{GJ} \mathrm{ha}^{-1}\right)$ than monocultures $\left(78.0 \mathrm{GJ}\right.$ ha $\left.{ }^{-1}\right)$. The output/ input ratio was greatest for rotated corn (14.0) and lowest for continuous soybean (9.9). Crop rotations that include legumes and reduced tillage improve the energy efficiency of crop production systems.
\end{abstract}

(C) 2007 Elsevier B.V. All rights reserved.

Keywords: Corn; Soybean; Tillage treatment; Crop rotation; Energy balance

\section{Introduction}

Discussions on environmental effects of crop production (e.g., greenhouse gas emissions) and consumption of non-renewable fossil energy resources

\footnotetext{
* Corresponding author. Tel.: +1 402472 1484; fax: +14024720516 .

E-mail address: Brian.Wienhold@ars.usda.gov (B.J. Wienhold).
}

require consistent information on the impact of crop specific activities and the sustainability of crop production systems. Energy parameters are meaningful indicators for assessing or comparing the environmental impacts from agricultural practices (Conforti and Giampietro, 1997; Kelm, 2004). Energy parameters can be used to assess the efficiency of production systems and to make comparisons among systems (Haciseferogullari et al., 2003). To evaluate the sustainability of agriculture, the energy efficiency of 
the system must be considered (Pervanchon et al., 2002). All inputs and outputs of a cropping system can be expressed in terms of energy. Hence, energy input and output are two important factors for determining the energy efficiency and environmental impact of crop production. However, energy utilization and output differs widely among crops, production systems and management intensity. Studies on energy utilization are strongly influenced by experimental plot data upon which the computations are based, system boundaries and methodology. Differences in management practices such as farm technology, tillage and crop rotation or intensity, have considerable effects on energy input and energy efficiency of crop production systems. Changes in farm technology over time have increased the amount of energy used in crop production. Energy use in USA agriculture increased more than six-fold from 1910 to 1978 and then declined 33\% from 1978 to 1990 (Cleveland, 1995a). This trend is consistent with data reported for other developed countries (Stirling, 1976; Conforti and Giampietro, 1997; Coxworth, 1997). Pimentel et al. (1973, 1990) and Smil et al. (1983) reported that the average energy input for corn production in the USA has increased from approximately $10 \mathrm{GJ} \mathrm{ha}^{-1}$ in 1945 to more than $30 \mathrm{GJ} \mathrm{ha}^{-1}$ in 1983.

Management practices (tillage, pesticides, fertilizer, crop, rotation) used within a crop production system affect the energy balance of that system. Many tillage systems are used in agriculture. The use of conservation and no-tillage is associated with lower energy inputs relative to conventional tillage systems such as moldboard plowing (Uri, 1999, 2000). However, no-till or conservation tillage systems often require increased pesticide use (Cannel and Hawes, 1994). Crop rotations have long been known to increase crop yields. Corn and soybean produce higher yields when grown in rotations than in monoculture (Crookston et al., 1991). Crop rotations with legumes are assumed to be energetically favorable to those without legumes due to reduced $\mathrm{N}$ fertilizer inputs (Strasil, 1990; Varvel and Wilhelm, 2003). Cropping systems that use commercial fertilizer, especially $\mathrm{N}$, use greater amounts of energy than systems that use no commercial fertilizer (Hülsbergen et al., 2001, 2002; Rathke et al., 2002; Rathke and Diepenbrock, 2006). Cleveland (1995b) suggested that energy productivity showed strong diminishing returns to increases in energy use per hectare of land. Swanton et al. (1996) concluded that energy use has decreased as crop yields have increased due to improved crop breeding resulting in increased energy efficiency in crop production. Hence, energy efficiency can be increased by decreasing energy use from inputs such as fertilizer or tillage operations or by increasing outputs such as crop yield (Swanton et al., 1996).

There is limited information available on long-term energy balances for corn and soybean related to tillage management and crop rotation. While there have been improvements in the fuel efficiency of machinery and energy use for $\mathrm{N}$ fertilizer production there is little information available on the effect these improvements have on field-scale energy balances. Long-term energy balance information for these crops would be useful for improving the efficiency of corn and soybean production systems. The aim of this study was to determine the effects of tillage treatment and crop rotation on the energy input and energy efficiency of corn and soybean production using yield results from a study in the Midwest USA (Wilhelm and Wortmann, 2004). The calculations were based on process analysis since this approach was considered to be the most suitable and accurate method for agricultural systems (Hülsbergen et al., 2001). An important aspect of this investigation was that the comparisons of different cropping systems were done under identical site conditions and used the same approach for calculating energy parameters, thus permitting a valid comparison across treatments.

\section{Materials and methods}

\subsection{Site description}

The trial was conducted at the University of Nebraska Rogers Memorial Farm $\left(40^{\circ} 51^{\prime} \mathrm{N}\right.$ and $96^{\circ} 28^{\prime} \mathrm{W}$, elevation $370 \mathrm{~m}$ ) near Lincoln, NE, from 1986 to 2001 . The soil was a Sharpsburg silty clay loam (USDA classification is a deep, moderately welldrained upland soil formed in loess; fine, smectitic, mesic Typic Argiudolls). During the experimental period the annual precipitation averaged $708 \mathrm{~mm}$ and the mean annual temperature was $10.6{ }^{\circ} \mathrm{C}$ (Wilhelm and Wortmann, 2004).

\subsection{Field experiment}

The field experiment was designed as a randomized complete block (six blocks) with a split-plot arrangement of treatments. Tillage treatments were assigned to whole plots and included chisel plow, ridge tillage, tandem disk, moldboard plow, no-tillage and subsoil tillage. Depth of primary tillage was approximately $10 \mathrm{~cm}$ for disk treatments, $25 \mathrm{~cm}$ for the chisel and plow treatments and $36 \mathrm{~cm}$ for the subsoil treatment. Subplot treatments were continuous corn, corn-soybean 
Table 1

Definitions of energy parameters in crop production

\begin{tabular}{|c|c|c|}
\hline Energy parameter & Definition & Unit \\
\hline Direct energy input $\left(E_{\mathrm{d}}\right)$ & Input for fuel ${ }^{\mathrm{a}}$ & $\mathrm{GJ} \mathrm{ha}^{-1}$ year $^{-1}$ \\
\hline Indirect energy input $\left(E_{\mathrm{i}}\right)$ & Seed + fertilizer + pesticides + machines & $\mathrm{GJ} \mathrm{ha}^{-1}$ year $^{-1}$ \\
\hline Total energy input $(E)$ & $E=E_{\mathrm{d}}+E_{\mathrm{i}}$ & $\mathrm{GJ} \mathrm{ha}^{-1}$ year $^{-1}$ \\
\hline Energy output $(\mathrm{EO})^{\mathrm{b}}$ & Energy in the harvested biomass & $\mathrm{GJ} \mathrm{ha}^{-1}$ year $^{-1}$ \\
\hline Energy gain (EG) & $\mathrm{EG}=\mathrm{EO}-E$ & $\mathrm{GJ} \mathrm{ha}^{-1}$ year $^{-1}$ \\
\hline Energy intensity (EI) & $\mathrm{EI}=E / \mathrm{GE}^{\mathrm{c}}$ & $\mathrm{MJ} \mathrm{GE}^{-1}$ year $^{-1}$ \\
\hline Output/input ratio (OI) & $\mathrm{OI}=\mathrm{EO} / E$ & \\
\hline
\end{tabular}

Source: Hülsbergen et al. (2001).

${ }^{a}$ Based on site- and yield-dependent data, which were subjected to regression analysis.

b Based on the calorific value.

${ }^{c}$ GE: Grain equivalents (Woermann, 1944).

rotation, continuous soybean and soybean-corn rotation so that each phase of all crop sequences was present in each year. Whole plots were $18.3 \mathrm{~m} \times 22.9 \mathrm{~m}$ and subplots were $4.6 \mathrm{~m} \times 22.9 \mathrm{~m}$.

Cultural practices were similar to those used by local producers. Planting densities varied from 40,000 to 58,000 seeds per hectare for corn and from 250,000 to 375,000 seeds per hectare for soybean. Pesticides were used in all treatments as needed. Insecticides were only applied to corn at planting. Herbicides were used for both corn and soybean. Each year, $\mathrm{N}$ was broadcast to corn at $113 \mathrm{~kg} \mathrm{~N} \mathrm{ha}^{-1}$ as ammonium nitrate $(34 \% \mathrm{~N})$ but no fertilizer was applied to soybean. Lime $(\mathrm{CaO})$ was applied in 1999 and 2001. Other plant nutrients were within optimum levels for corn and soybean. All crops were harvested after reaching physiological maturity.

In order to extrapolate the data to a farm-level basis a field size and type of equipment common to the region were assumed. An average field size of 50 ha and an average farm-to-field distance of $5 \mathrm{~km}$ was used. Energy inputs associated with machinery operations for each of the treatments included in this analysis were based on selection of equipment typically used on commercial farms in the area.

\subsection{Energy balance calculations}

Energetic calculations based on process analysis consider non-renewable energy inputs but not manpower and solar energy (Hülsbergen et al., 2001). Manpower represents a very small percentage $(<0.02 \%)$ of energy input for production systems in developed countries (Zentner et al., 1984; Borin et al., 1997). Solar radiation exceeds the input of fossil energy by three orders of magnitude and its incorporation in the energy balance would mask variation in the input of fossil energy related to different treatments (Rathke,
1999; Hülsbergen et al., 2001). Direct and indirect fossil energy parameters used in crop production are presented in Table 1. The model for determining total fossil energy input consists of two submodels: (i) a model that related field operations to fuel consumption and (ii) a model that related other production inputs to a corresponding non-renewable energy equivalent (Kelm, 2004). Fuel consumption of field operations was based on equations that were estimated using regression analysis of distance to fields, working width, depths of tillage and yield (Table 2) (Kalk and Hülsbergen, 1999). Indirect energy inputs for seed, plant protection agents, fertilizers and machines, were obtained by multiplying the amount used by a specific energy coefficient (Table 3). Energy inputs for drying, storage and transport of grain from the farm to consumers were

Table 2

Fuel consumption by field operation $\left(1 \mathrm{ha}^{-1}\right)^{\mathrm{a}}$

\begin{tabular}{lc}
\hline Treatment & Fuel consumption \\
\hline Chopping & $4.72-4.97$ \\
Tillage treatment & \\
$\quad$ Chisel plow & $11.65-12.27$ \\
Tandem disk & $7.16-7.54$ \\
Moldboard plow & $33.27-35.03$ \\
Ridge-tillage & $8.28-8.72$ \\
Subsoil-tillage & $14.50-15.27$ \\
Planting & \\
$\quad$ With tillage & $6.75-7.10$ \\
Direct seed & $9.56-10.06$ \\
Fertilization & $7.84-8.25$ \\
Pesticide application & $1.96-2.06$ \\
Harvesting & $8.36-23.3$ \\
\hline
\end{tabular}

Source: From Kalk and Hülsbergen (1999).

${ }^{\text {a }}$ Differences within one treatment due to modified machinery and working width during the experimental period. First value for experimental period 1986-1990 and second value for 1996-2001.

${ }^{\mathrm{b}}$ Values for harvesting adapted to different conditions (working width, yield) by regression equations. 
Table 3

Energy coefficients for indirect inputs

\begin{tabular}{llll}
\hline Item & Energy coefficient & Unit & Reference \\
\hline Seeds & 15.6 & $\mathrm{MJ} \mathrm{kg}^{-1}$ & Smil et al. (1983) \\
$\quad$ Corn & 23.8 & $\mathrm{MJ} \mathrm{kg}^{-1}$ & Author estimate \\
$\quad$ Soybean & 39.6 & $\mathrm{MJ} \mathrm{l}^{-1}$ & Reinhardt (1993) \\
$\begin{array}{l}\text { Diesel fuel } \\
\text { Mineral fertilizer }\end{array} \quad$ & $\mathrm{MJ} \mathrm{kg}^{-1}$ & Appl (1997), Jenssen and Kongshaug (2003) \\
$\quad$ Nitrogen & $32.2-49.4^{\mathrm{a}}$ & & Green (1987) \\
$\begin{array}{l}\text { Pesticides } \\
\text { Herbicides }\end{array}$ & $288^{\mathrm{b}}$ & $\mathrm{MJ} \mathrm{kg}^{-1}$ a.i. & Kalk and Hülsbergen (1999) \\
Machinery & $108^{\mathrm{c}}$ & $\mathrm{MJ} \mathrm{kg}^{-1}$ & \\
\hline
\end{tabular}

${ }^{\mathrm{a}}$ Energy coefficients shown for mineral nitrogen fertilizer averaged $49.4 \mathrm{MJ} \mathrm{kg}^{-1}$ for 1986-1991, $35.3 \mathrm{MJ} \mathrm{kg}^{-1}$ for $1992-1996$ (Appl, 1997 , modified by Hülsbergen et al., 2001) and $32.2 \mathrm{MJ} \mathrm{kg}^{-1}$ for 1997-2002 (Jenssen and Kongshaug, 2003).

${ }^{\mathrm{b}}$ Units of measure are active ingredient (a.i.). Mean input of primary energy according to Green (1987) plus energy inputs for transport and storage (Hülsbergen et al., 2001).

${ }^{c}$ Includes energy required for manufacture and maintenance.

not considered. In eastern Nebraska grain drying after harvest is usually not required but may be a significant energy input in other parts of the Corn Belt. No allowance was made for energy removed from the soil in the form of plant nutrients or soil organic matter increases or losses (Coxworth et al., 1995a,b; Zentner et al., 2004). Energy equivalents for all inputs were summed to provide an estimate for total energy input (Table 1).

In conducting long-term experiments, an attempt is usually made to keep treatments as constant as possible. In this study, improvements in fuel use efficiency and energy consumption for fertilization production were taken into account. It was assumed that the working width of machines increased, while the energy equivalent for mineral fertilizer declined during the experimental period. Reports from the University of Nebraska Tractor Test Laboratory show improved fuel efficiency during the past 20 years. Hence, typical fuel consumption rates for machines and tractors typical for three time periods (1986-1990, 1991-1995 and 1996-2001) were used. Similarly, the energy equivalent for mineral $\mathrm{N}$ fertilizer was assumed to be $49.4 \mathrm{MJ} \mathrm{kg}^{-1}$ for $1986-1990$, $35.3 \mathrm{MJ} \mathrm{kg}^{-1}$ for $1991-1995$ and $32.2 \mathrm{MJ} \mathrm{kg}^{-1}$ for 1996-2001 reflecting improvements in production efficiency. The values for the first two periods were based on calculations of Appl (1997) as modified by Hülsbergen et al. (2001) and the value for the third period was that reported by Jenssen and Kongshaug (2003). Since the exact energy equivalents of plant protection agents used in this study were unknown, mean values given by Green (1987) were assumed.

Energy output from the cropping system was based on the main product, the corn and soybean grain. Crop residue was not included as energy output since it remained in the field. The energy output was computed by multiplying the dry matter yield by the caloric value (15.6 $\mathrm{MJ} \mathrm{kg}^{-1}$ for corn and $23.8 \mathrm{MJ} \mathrm{kg}^{-1}$ for soybean) using the method of Schiemann (1981). The caloric values was strongly correlated to the biochemical composition of the crop material.

Energy efficiency can be expressed in terms of energy gain (also called net energy output), energy intensity and output/input ratio, which are derived from the fossil energy input and the crop energy output (Table 1). Energy gain $\left(\mathrm{GJ} \mathrm{ha}^{-1}\right)$ is the difference between total energy output and total energy input. Energy intensity ( $\mathrm{MJ} \mathrm{GE}^{-1}$ ) represents total energy input per unit grain equivalent (GE). The term GE (also known as cereal unit) was established by Woermann (1944) to express the contribution that crops make to the nutrition of monogastrics. It is a measure used mainly in agricultural and nutritional statistics at the national level (Kelm, 2004). By converting the yield into GE, yields of crops that differ in chemical composition and energetic value can be aggregated. This allows direct comparison of yields across crop rotations and farming systems (Hülsbergen et al., 2001). Yield was converted into grain equivalents by assuming $1.10 \mathrm{GE} \mathrm{dt}{ }^{-1}$ corn and $1.20 \mathrm{GE} \mathrm{dt}^{-1}$ soybean (Woermann, 1944). The dimensionless output/input ratio was determined by dividing the energy output by the energy input.

\subsection{Statistical analyses}

Data were analyzed as a repeated measures split-plot design with years treated as a random effect, while block, tillage and rotation effects were considered fixed. 
All measured parameters were subjected to analyses of variance using SAS PROC MIXED (Littell et al., 1996) applying the restricted likelihood method to estimate the variance components (SAS Inst. Inc., Cary, NC, USA). The Kenward-Roger method was used to estimate degrees of freedom (Kenward and Roger, 1997). Differences were considered significant at $p<0.05$ and differences among treatment means were determined using least significant difference (LSD).

\section{Results}

We found significant interaction between treatment factors (tillage and crop rotation) and years for energy input and energy efficiency. The variation among years emphasizes the importance that weather has on the development and yield of crops (Wilhelm and Wortmann, 2004) and in turn, on the energy output and energy efficiency. It also demonstrates the importance of long-term studies. In spite of the variation among years, the response of calculated energy parameters to tillage treatment and crop rotation had the same rank order, indicating the interaction with years was related to magnitude of response, not direction of response. The effects of the treatment factors and their interactions are presented across years to simplify their interpretation.

\subsection{Energy input}

Total fossil energy input and the relative share of each input factor on the total consumption of fossil energy varied widely. Over the 16-year study period, the lowest energy inputs were calculated for 1998 $\left(6.50 \mathrm{GJ} \mathrm{ha}^{-1}\right)$ and 1996 (6.51 GJ ha $\left.{ }^{-1}\right)$, while the highest values occurred in $1999\left(12.1 \mathrm{GJ} \mathrm{ha}^{-1}\right)$. The large range in energy input resulted from the lime applications in 1999 and 2001 increasing energy inputs for those years.

Across years, energy input of tillage treatments increased in the order no-till $\left(7.34 \mathrm{GJ} \mathrm{ha}^{-1}\right)<$ tandem disk $\quad\left(7.65 \mathrm{GJ} \mathrm{ha}^{-1}\right) \approx$ ridge-till $\quad\left(7.69 \mathrm{GJ} \mathrm{ha}^{-1}\right)<$ chisel plow $\left(7.83 \mathrm{GJha}^{-1}\right) \approx$ subsoil-tillage $(7.96 \mathrm{GJ}$ $\left.\mathrm{ha}^{-1}\right)<$ moldboard plow $\left(8.72 \mathrm{GJ} \mathrm{ha}^{-1}\right)$. There was a $19 \%$ difference in energy input between the moldboard plow tillage and no-tillage treatments. Among crops, soybean required the lower and corn the higher energy input (Fig. 1). Higher energy input for corn was the result of $\mathrm{N}$ fertilization and higher fuel use. Combining the impact of tillage treatment and crop rotation resulted in the highest energy input occurring in plowed corn grown in monoculture $\left(10.6 \mathrm{GJ} \mathrm{ha}^{-1}\right)$ and the lowest occurring in continuous soybean with no-tillage (5.43 GJ ha ${ }^{-1}$ ) (Fig. 1).

The two largest components of energy input were related to fertilizer and fuel consumption (data not shown). Fertilizer-related energy input was more important than fuel consumption in corn production, while fuel consumption was more important in soybean production systems, because no fertilizer was applied to the soybean crop. Averaged across all years, N fertilization accounted for $40-60 \%$ of the total energy input for corn production. Fuel consumption for both corn and soybean varied according to tillage treatment, planting, fertilization, plant protection and harvest. Fuel consumption comprised $17-36 \%$ of total energy input

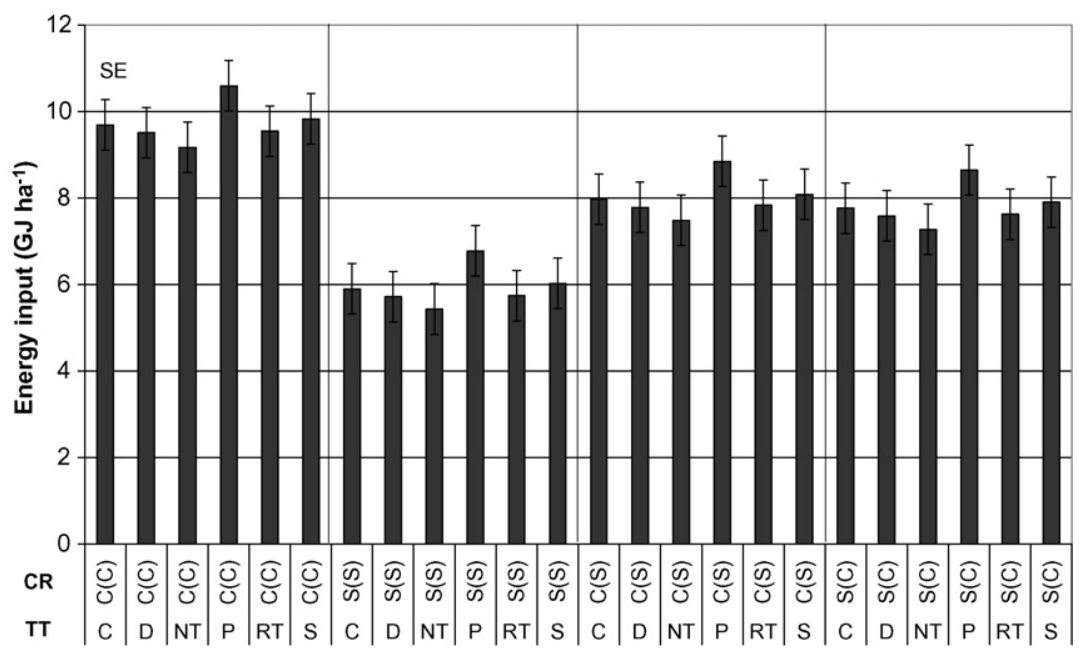

Fig. 1. Mean energy input (GJ ha ${ }^{-1}$ ) as a function of tillage treatment (TT) and crop rotation (CR). Error bar represents one standard error of the mean. Tillage treatments are C, chisel plow; D, tandem disk; NT, no-tillage; P, moldboard plow; RT, ridge-tillage and S, subsoil tillage. Crop rotations are $\mathrm{C}(\mathrm{C})$, continuous corn; $\mathrm{S}(\mathrm{S})$, continuous soybean; $\mathrm{C}(\mathrm{S})$, corn in corn/soybean rotation; $\mathrm{S}(\mathrm{C})$, soybean in soybean/corn rotation. 
for corn compared to $30-51 \%$ for soybean. Independent of crop and crop rotation, fuel consumption comprised the lowest percentage of total energy input in the no-till treatment and the highest percentage of total energy input in the plow treatment. The proportion of total energy input accounted for by pesticides ranged from 11 to $19 \%$ for corn to 7 to $31 \%$ for soybean. In this study pesticides within a crop were applied uniformly across tillage treatments.

\subsection{Energy output}

Yearly energy output of a crop rotation varied directly with grain yield and energy content of the grain. Corn and soybean yields both exhibited year-to-year variation due to weather (Wilhelm and Wortmann, 2004). Averaged across crops there were no differences in energy output among the tillage treatments (93.25 $\mathrm{GJ} \mathrm{ha}^{-1}$ ). Among the crop rotations the energy output for continuous corn averaged $106 \mathrm{GJ} \mathrm{ha}^{-1}$ and was similar to the $108 \mathrm{GJ} \mathrm{ha}^{-1}$ for corn in a corn/ soybean rotation. In contrast, the energy output for continuous soybean averaged $63.9 \mathrm{GJ} \mathrm{ha}^{-1}$ compared to $95.6 \mathrm{GJ} \mathrm{ha}^{-1}$ for soybean in a soybean/corn rotation. This outcome was a direct result of the yield difference found in this study between continuous soybean $\left(2.35 \mathrm{Mg} \mathrm{ha}^{-1}\right)$ and soybean in rotation with corn (2.58 $\mathrm{Mg} \mathrm{ha}^{-1}$ ) (Wilhelm and Wortmann, 2004). Hence, there was an increase in energy output for soybean grown in a rotation. However, the energy output for soybean was lower than that for corn. Higher energy output for corn related to the two- to three-fold higher yield for corn $\left(6.47 \mathrm{Mg} \mathrm{ha}^{-1}\right)$ than for soybean (2.46 $\mathrm{Mg} \mathrm{ha}^{-1}$ ) (Wilhelm and Wortmann, 2004). Energy output as a function of tillage treatment and crop rotation was lowest for continuous soybean with ridge tillage $\left(62.6 \mathrm{GJ} \mathrm{ha}^{-1}\right)$ and highest for continuous corn with moldboard plow tillage $\left(115 \mathrm{GJ} \mathrm{ha}^{-1}\right)$ (Fig. 2). The energy output for corn in monoculture or in a corn/soybean rotation exhibited a similar pattern to tillage with lowest values associated with no-tillage and highest values associated with moldboard plow tillage. The energy output for soybean was similar across tillage treatments (Fig. 2). Over the 16 years of this study, the lowest energy output occurred in 1995 $\left(54.2 \mathrm{GJ} \mathrm{ha}^{-1}\right)$ while the highest energy output occurred in $1992\left(141 \mathrm{GJ} \mathrm{ha}^{-1}\right)$ reflecting weather effects on yield (Wilhelm and Wortmann, 2004).

\subsection{Energy efficiency}

Averaged over crop sequences and years, energy gain was similar across tillage treatments and averaged $85.4 \mathrm{GJ} \mathrm{ha}^{-1}$. Among crop rotations, the energy gain increased from $58.0 \mathrm{GJ} \mathrm{ha}^{-1}$ for continuous soybean to $87.8 \mathrm{GJ} \mathrm{ha}^{-1}$ for soybean in rotation. The energy gain for corn in rotation with soybean $\left(97.8 \mathrm{GJ} \mathrm{ha}^{-1}\right)$ was similar to that for continuous corn $\left(98.0 \mathrm{GJ} \mathrm{ha}^{-1}\right)$. When compared among tillage and crop rotations the energy gain was lowest for continuous soybean regardless of tillage practice $\left(56.4 \mathrm{GJ} \mathrm{ha}^{-1}\right)$ and was greatest for continuous corn with plow tillage (104 GJ ha ${ }^{-1}$ ) (Fig. 3). As with the other energy parameters, there was large variation from year-to-year



Fig. 2. Mean energy output (GJ ha ${ }^{-1}$ ) as a function of tillage treatment (TT) and crop rotation (CR). Error bar represents one standard error of the mean. Tillage treatments are C, chisel plow; D, tandem disk; NT, no-tillage; P, moldboard plow; RT, ridge-tillage and S, subsoil tillage. Crop rotations are $\mathrm{C}(\mathrm{C})$, continuous corn; $\mathrm{S}(\mathrm{S})$, continuous soybean; $\mathrm{C}(\mathrm{S})$, corn in corn/soybean rotation; $\mathrm{S}(\mathrm{C})$, soybean in soybean/corn rotation. 


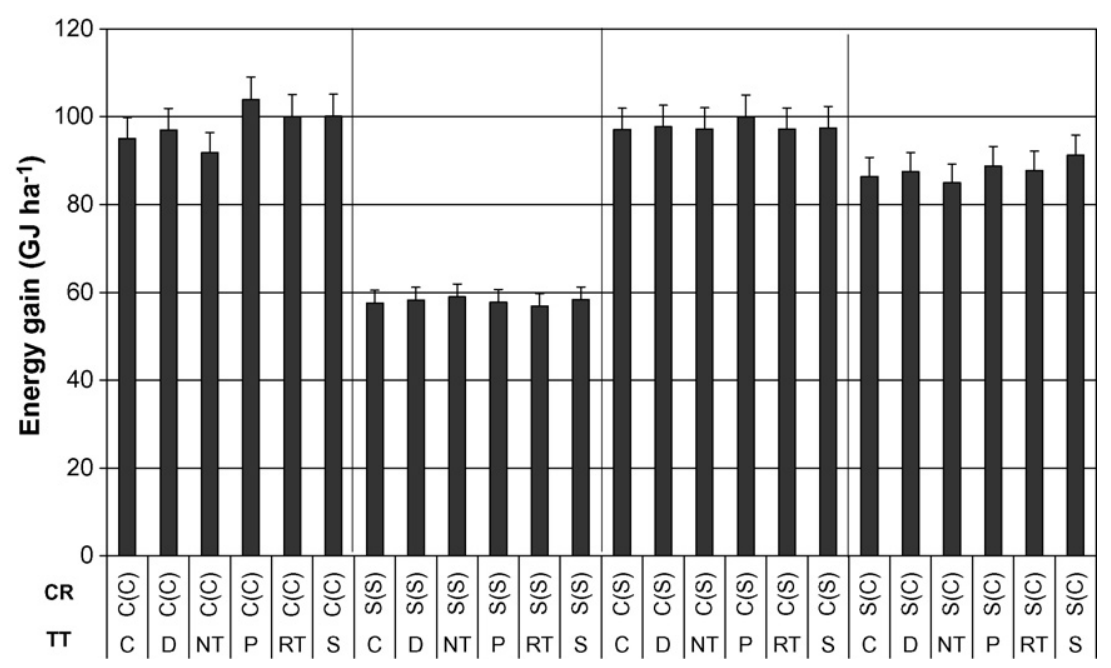

Fig. 3. Mean energy gain (GJ ha ${ }^{-1}$ ) as a function of tillage treatment (TT) and crop rotation (CR). Error bar represents one standard error of the mean. Tillage treatments are $\mathrm{C}$, chisel plow; D, tandem disk; NT, no-tillage; P, moldboard plow; RT, ridge-tillage and S, subsoil tillage. Crop rotations are $\mathrm{C}(\mathrm{C})$, continuous corn; $\mathrm{S}(\mathrm{S})$, continuous soybean; $\mathrm{C}(\mathrm{S})$, corn in corn/soybean rotation; $\mathrm{S}(\mathrm{C})$, soybean in soybean/corn rotation.

with average energy gain being lowest in 1995 (47.6 GJ ha ${ }^{-1}$ ) and highest in $1992\left(134 \mathrm{GJ} \mathrm{ha}^{-1}\right)$.

Energy intensity (ratio of total energy input to grain equivalent) differed among tillage treatments being lowest in ridge-till and no-tillage and increasing in the order tandem disk $\approx$ chisel plow $\approx$ subsoil tillage $<$ moldboard plow (Fig. 4a). Energy intensity also differed among the crop rotations being lowest in soybean in rotation with corn and highest in continuous soybean (Fig. 4b). Energy intensity varied among years and averaged from 96.4 $\mathrm{MJ} \mathrm{GE}^{-1}$ in 1992 to $259 \mathrm{MJ} \mathrm{GE}^{-1}$ in 1987.

The output/input ratio was lower for moldboard plow tillage than for the other tillage practices (Fig. 5a). The output/input ratio was similar between continuous corn and soybean and between both crops grown in rotation, but greater for both crops when they were grown in rotation than in monoculture (Fig. 5b). When compared across tillage and crop treatments, the output/input ratio ranged from 9.93 for continuous soybean with moldboard plow tillage to 14.0 for no-tillage corn in rotation (Fig. 6). Over the 16-year study, the output/input ratio ranged from 3.69 to 23.6. The lowest value was associated with continuous corn and tandem disk tillage in 1995 and the highest ratio was associated with notillage soybean in rotation in 1998. Year-to-year variation in output/input ratio ranged from 7.41 (2001) to 18.5 (1992) (data not shown).

\section{Discussion}

Most energy balance research has been directed at single crops like corn (McKyes and Owen, 1986;
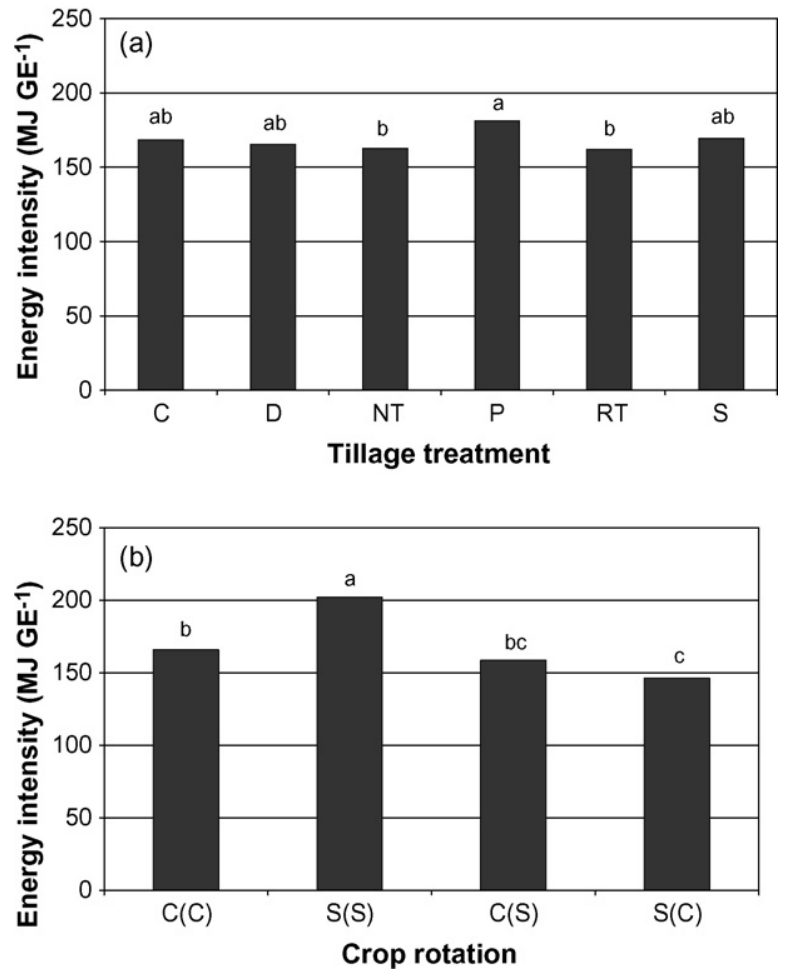

Fig. 4. Mean energy intensity ( $\mathrm{MJ} \mathrm{GE}^{-1}$ ) as a function of (a) tillage treatment and (b) crop rotation. Means with the same letter are not significantly different at $p=0.05$. C, Chisel plow; D, tandem disk; NT, no-tillage; $\mathrm{P}$, moldboard plow; RT, ridge-tillage and $\mathrm{S}$, subsoil tillage. $\mathrm{C}(\mathrm{C})$, Continuous corn; $\mathrm{S}(\mathrm{S})$, continuous soybean; $\mathrm{C}(\mathrm{S})$, corn in corn/ soybean rotation; $\mathrm{S}(\mathrm{C})$, soybean in soybean/corn rotation. 

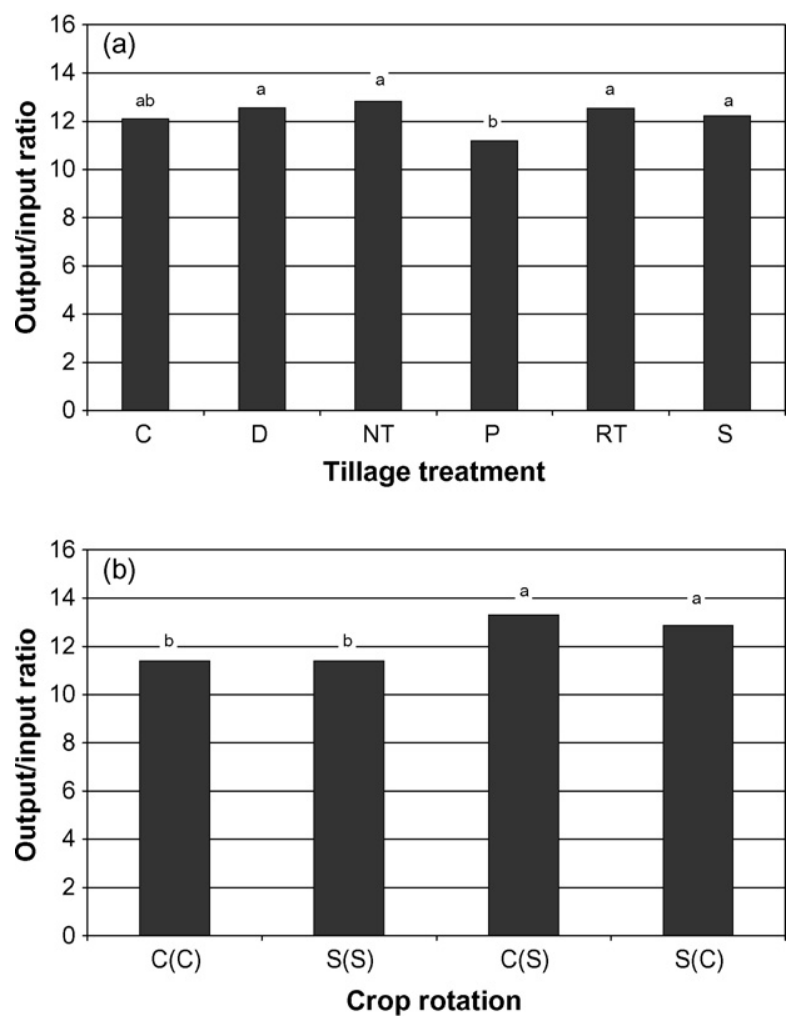

Fig. 5. Mean energy output/input ratio as a function of (a) tillage treatment and (b) crop rotation. Means with the same letter are not significantly different at $p=0.05$. C, Chisel plow; D, tandem disk; NT, no-tillage; $\mathrm{P}$, moldboard plow; RT, ridge-tillage and $\mathrm{S}$, subsoil tillage. $\mathrm{C}(\mathrm{C})$, Continuous corn; $\mathrm{S}(\mathrm{S})$, continuous soybean; $\mathrm{C}(\mathrm{S})$, corn in corn/ soybean rotation; $\mathrm{S}(\mathrm{C})$, soybean in soybean/corn rotation.
Franzluebbers and Francis, 1995; McLaughlin et al., 2000), sorghum (Sorghum bicolor (L.) Moench) (Franzluebbers and Francis, 1995; Monti and Venturi, 2003) or winter wheat (Triticum aestivum L.) (Küsters and Lammel, 1999; Rosenberger et al., 2001; Ceccon et al., 2002; Monti and Venturi, 2003), with fewer studies looking at crop rotations (Zentner et al., 1989; Hülsbergen et al., 2001, 2002; Ceccon et al., 2002; Rathke et al., 2002). Differences in the choice of scale and boundaries of the analysis, accuracy of energy-use data and goals of the analysis, make it difficult to compare results among studies. The present study compared the energy balance of corn and soybean under various tillage and crop rotation treatments. Differences in input requirements and yields for corn and soybean resulted in a large variation in energy balance results among treatments. Since our study was conducted at a single site, a number of potential sources of variation could be documented (e.g., management practices, weather, soils and varieties). Using a similar approach to calculate energy parameters across treatments provided a valid comparison for treatment effects for these two crops grown continuously or in rotation.

Reported energy input values vary from $19 \mathrm{GJ} \mathrm{ha}^{-1}$ (Wang et al., 1997) to $33 \mathrm{GJ} \mathrm{ha}^{-1}$ (Pimentel, 2003) and $36 \mathrm{GJ} \mathrm{ha}^{-1}$ (Ceccon et al., 2002) for corn production and from less than $10 \mathrm{GJ} \mathrm{ha}^{-1}$ to almost $17 \mathrm{GJ} \mathrm{ha}^{-1}$ for soybean (Ceccon et al., 2002). We estimated energy input values lower than those previously published due to differences in the choice of scale and boundaries of the analysis, energy equivalents used in the calculations and calculation methods. The extremely high energy

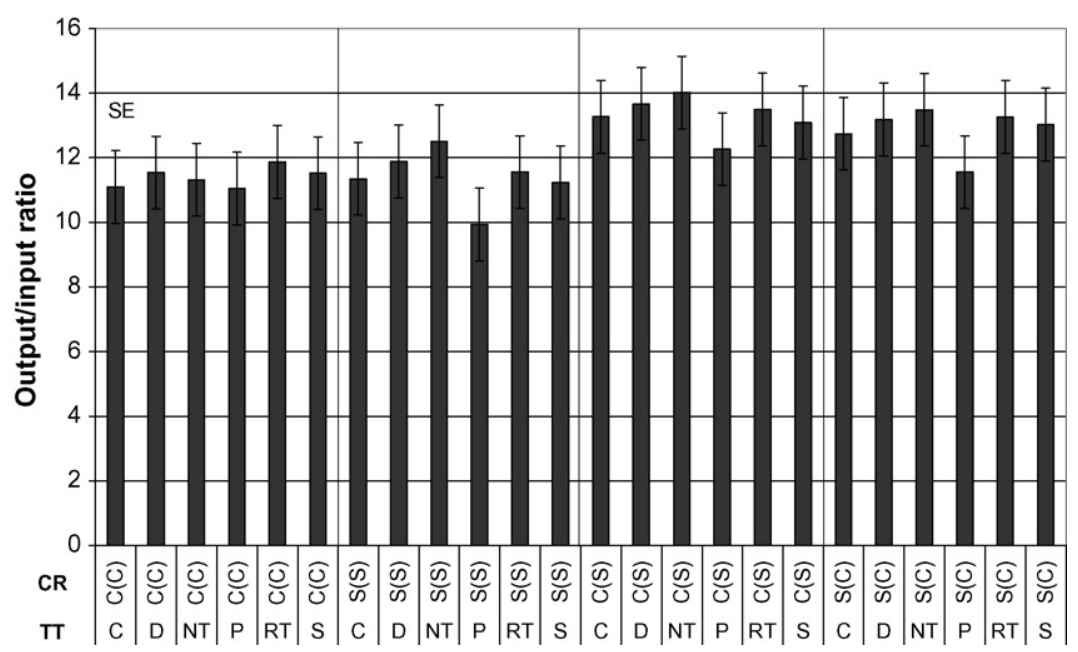

Fig. 6. Mean energy output/input ratio as a function of tillage treatment (TT) and crop rotation (CR). Error bar represents one standard error of the mean. Tillage treatments are C, chisel plow; D, tandem disk; NT, no-tillage; P, moldboard plow; RT, ridge-tillage and S, subsoil tillage. Crop rotations are $\mathrm{C}(\mathrm{C})$, continuous corn; $\mathrm{S}(\mathrm{S})$, continuous soybean; $\mathrm{C}(\mathrm{S})$, corn in corn/soybean rotation; $\mathrm{S}(\mathrm{C})$, soybean in soybean/corn rotation. 
input value for corn given by Ceccon et al. (2002) was based on an average $\mathrm{N}$ rate of $257 \mathrm{~kg} \mathrm{ha}^{-1}$, an energy equivalent of $73.3 \mathrm{MJ} \mathrm{kg}^{-1}$ and inclusion of $5.40 \mathrm{GJ} \mathrm{ha}^{-1}$ for irrigation. In spite of these differences, across all studies fertilization and fuel consumption accounted for the highest share of total energy input while seeds and pesticides contributed little (Zentner et al., 1989; Pimentel et al., 1990; Ceccon et al., 2002; Hülsbergen et al., 2001).

Our results confirmed the importance of fertilization and fuel consumption on total energy input. The proportion of total energy input that $\mathrm{N}$ fertilizer contributed to corn production in our study was similar to that reported by Clements et al. (1995). Nitrogen fertilizer's large contribution to energy input for corn compared to soybean is the result of soybean's ability to support N fixing bacteria (Swanton et al., 1996). Since $\mathrm{N}$ fertilization does not contribute to energy input for soybean, fuel consumption contributes a larger proportion to soybean energy input than to corn energy input. We also reported that the lowest percentage of energy input occurred in the no-till system and the highest in systems with moldboard plow treatment. These results supported the conclusions of several earlier investigations that the energy input for fuel consumption can be reduced with no-tillage management (Boerma et al., 1980; Smith and Fornstorm, 1980; Franzluebbers and Francis, 1995; Borin et al., 1997) and that the highest energy use occurred with moldboard plowing (Bailey et al., 2003). Borin et al. (1997) calculated energy savings of $10 \%$ with ridge-till and $32 \%$ with no-till compared to moldboard plow. In contrast, Zentner et al. (2004) reported that energy use for complete cropping systems was largely unaffected by tillage method and that it differed significantly among crop rotations. Further, the use of minimum and no-till practices provided significant energy savings compared to conventional tillage practices in on-farm use of fuel for some cropping system components (e.g., summer fallow preparation, spring wheat grown on pea (Pisum sativum L.) stubble and for pea grown on cereal stubble). However, these savings were often offset by higher energy requirements for herbicides and for $\mathrm{N}$ fertilizer with conservation tillage management (Zentner et al., 2004). O'Callaghan (1994) reported that when conventional and direct-seeding tillage methods were compared, the energy savings related to tillage are insignificant in comparison with the other required energy inputs. The apparent savings in energy through the use of direct seeding was cancelled by the increased amount of $\mathrm{N}$ fertilizer required to maintain yields at levels similar to conventionally tilled systems
(O'Callaghan, 1994). Energy used for tillage and herbicides depends on the type of weed management system used (Swanton et al., 1996). Although pesticides tend to be energy intensive to manufacture (Green, 1987) their contribution to the total energy input is relatively small because of low application rates (Clements et al., 1995). Others have reported that the percentage of energy input attributed to pesticides was 4-7\% for corn and 17-20\% for soybean (Clements et al., 1995; Swanton et al., 1996). We reported slightly higher percentages for corn (11-19\%) and soybean $(7-31 \%)$.

Our results for the energy output of soybean were similar to values given by Ceccon et al. (2002), who calculated energy outputs of 59.6 and $71.6 \mathrm{GJ} \mathrm{ha}^{-1}$ for soybean grown in northeastern Italy. However, Ceccon et al. (2002) reported a higher energy output $\left(189 \mathrm{GJ} \mathrm{ha}^{-1}\right)$ for corn after soybean. The high energy output for corn after soybean was likely due to their study being conducted under irrigation while ours was not and hence their yields were greater than ours. Zentner et al. $(1998,2004)$ found that tillage method had little influence on the level of energy output from various production systems, which was similar to our findings. The differential response of corn and soybean to tillage treatments may have been the result of later planting dates for soybean than for corn, thereby reducing the effect of low early-season soil temperatures on germination and seedling vigor (Wilhelm and Wortmann, 2004). Borin et al. (1997) and Küsters and Lammel (1999) reported that energy output increased with increasing energy input. Borin et al. (1997) reported that energy outputs were highest in systems using moldboard plow tillage and lowest in no-till systems. Opposite results were reported by Zentner et al. $(1998,2004)$ who found that energy output was generally lower with conventional tillage (sweep cultivator) than with minimum or no-till management.

There is currently no standardized approach for determining the optimum level of energy input per area of agricultural land (Küsters and Lammel, 1999) or unit output. A number of energy parameters are available for determining the energy efficiency of crop production systems including the parameters we computed; energy gain (net energy output), energy intensity and output/ input ratio. Maximizing energy gain is desirable when the land is used to produce renewable energy (Kuemmel et al., 1998) or when the demand for plant production cannot be met because of the limited area for growing crops (Hülsbergen et al., 2001). There is a strong correlation between both energy gain and energy output with energy gain increasing as long as the energy output 
per unit energy input increases. Energy intensity and output/input ratio are measures of the environmental effects associated with the production of crops. Küsters and Lammel (1999) and Hülsbergen et al. (2001) noted that the highest output/input ratios were achieved at low production intensities and declined with increasing production intensity and our results supported their findings.

Management systems with a legume as a previous crop have been reported as having a greater energy output/input ratio than those with a cereal as the previous crop (Franzluebbers and Francis, 1995; Rathke and Diepenbrock, 2006). We also observed that both corn and soybean achieved higher output/input ratios when grown in a crop rotation than when grown in a monoculture. Franzluebbers and Francis (1995) also reported that the output/input ratio for traditional tillage systems (chisel plow) and no tillage systems was similar under dryland conditions in eastern Nebraska. Based on investigations for spring wheat, Zentner et al. (1998) concluded that the potential of achieving energy savings by adopting conservation tillage management was low in the semiarid region. In contrast, Küsters and Lammel (1999) reported that the highest energy output/input ratio occurred at the lowest production intensity. Borin et al. (1997) found that the output/input ratio tended to increase when soil tillage operations were reduced, which are similar to our results.

\section{Conclusions}

The results of the 16-year study show that the energy efficiency of corn and soybean responded mainly to management strategies. Crop rotation, inclusion of a legume in the rotation and reduced tillage resulted in improved energy efficiency. Energy output was temporally dynamic because of the effect weather had on crop yields. This long-term study was well suited to assess treatment differences under temporally variable conditions. Within crop rotations, $\mathrm{N}$ fertilizer was the largest energy input. While there have been improvements in the energy efficiency of producing $\mathrm{N}$ fertilizer there is a great need to improve crop $\mathrm{N}$-use efficiency. Improved N-use efficiency will improve the energy efficiency of crop production systems.

\section{Acknowledgement}

The authors wish to thank the OECD for financial support for the senior author within the "Co-Operative Research Program 2004: Biological Resource Management for Sustainable Agricultural Systems".

\section{References}

Appl, M., 1997. Ammonia, Methanol Hydrogen, Carbon MonoxideModern Production Technologies. CRU, London.

Bailey, A.P., Basford, W.D., Penlington, N., Park, J.R., Keatinge, J.D.H., Rehman, T., Tranter, R.B., Yates, C.M., 2003. A comparison of energy use in conventional and integrated arable farming systems in the UK. Agric. Ecosyst. Env. 97, 241-253.

Boerma H., Gimby, M., Coxworth, E., 1980. A study of energy consumption of different practices in Saskatchewan. Year III. Tech. Report No. 103, Publ. No. C-185-1-b-80. SaskatchewanResearch Council, Saskatoon, Sask., 35 pp.

Borin, M., Menini, C., Sartori, L., 1997. Effect of tillage system on energy and carbon balance in north-eastern Italy. Soil Till. Res. 40, 209-226.

Cannel, R., Hawes, J.D., 1994. Trends in tillage practices in relation to sustainable crop production with special reference to temperate climates. Soil Till. Res. 30, 245-282.

Ceccon, P., Coiutti, C., Giovanardi, R., 2002. Energy balances of four farming systems in north-eastern Italy. Ital. J. Agron. 6 (1), 73-83.

Clements, D.R., Weise, S.F., Brown, R., Stonehouse, D.P., Hume, D.J., Swanton, C.J., 1995. Energy analysis of tillage and herbicide inputs in alternative weed management systems. Agric. Ecosyst. Env. 52 (2-3), 119-128.

Cleveland, C.L., 1995a. The direct and indirect use of fossil energy and electricity in USA agriculture, 1910-1990. Agric. Ecosyst. Env. 55, 111-121.

Cleveland, C.L., 1995b. Resource degradation, technical changes, and the productivity of energy us in US. Ecol. Econ. 13 (3), 185-201.

Conforti, P., Giampietro, M., 1997. Fossil energy use in agriculture: an international comparison. Agric. Ecosyst. Env. 65, 231-243.

Coxworth, E., 1997. Energy use trends in Canadian agriculture: 19901996. Report to Canadian Agricultural Energy End Use Data Analysis Centre. University of Saskatchewan, Saskatoon, Sask., $26 \mathrm{pp}$.

Coxworth, E., Entz, M.H., Leduc, P., Burton, G., 1995a. Study of the effects of cropping and tillage systems on the carbon dioxide released by manufactured inputs to western Canadian agriculture: identification of methods to reduce carbon dioxide emissions. Final Report, vol. 1. Agriculture and Agri-Food Canada Green Plan Program. Scientific Authority: H. Janzen, Agriculture and Agri-Food Canada Res. Centre, Lethbridge, AB, April, 44 pp.

Coxworth, E., Entz, M.H., Leduc, P., Burton, G., 1995b. Study of the effects of cropping and tillage systems on the carbon dioxide released by manufactured inputs to western Canadian agriculture: identification of methods to reduce carbon dioxide emissions. Final Report, vol. 2. Agriculture and Agri-Food Canada Green Plan Program. Scientific Authority: H. Janzen, Agriculture and Agri-Food Canada Res. Centre, Lethbridge, AB, May, $90 \mathrm{pp}$.

Crookston, R.K., Kurle, J.E., Copeland, P.J., Ford, J.H., Lueschen, W.E., 1991. Rotational cropping sequences affects yield of corn and soybean. Agron. J. 83, 108-113.

Franzluebbers, A.J., Francis, C.A., 1995. Energy output:input ratio of maize and sorghum management systems in eastern Nebraska. Agric. Ecosyst. Env. 53, 271-278.

Green, M.B., 1987. Energy in pesticide manufacture, distribution and use. In: Helsel, Z.R. (Ed.), Energy in Plant Nutrition and Pest Control. Elsevier, Amsterdam, pp. 165-177.

Haciseferogullari, H., Acaroglu, M., Gezer, I., 2003. Determination of the energy balance of the sugar beet plant. Energy Sources 25 (1), $15-22$. 
Hülsbergen, K.-J., Feil, B., Biermann, S., Rathke, G.-W., Kalk, W.-D., Diepenbrock, W., 2001. A method of energy balancing in crop production and its application in a long-term fertilizer trial. Agric. Ecosyst. Env. 86, 303-321.

Hülsbergen, K.-J., Feil, B., Diepenbrock, W., 2002. Rates of nitrogen application required to achieve maximum energy efficiency for various crops: results of a long-term experiment. Field Crops Res. 77, 61-76.

Jenssen, T.K., Kongshaug, G., 2003. Energy consumption and greenhouse gas emissions in fertiliser production. In: Proceedings No. 509, The International Fertiliser Society (ifs), York.

Kalk, W.-D., Hülsbergen, K.-J., 1999. Dieselkraftstoffeinsatz in der Pflanzenproduktion. Landtechnik 54 (6), 332-333.

Kelm, M., 2004. Strategies for sustainable agriculture with particular regard to productivity and fossil energy use in forage production on organic arable farming. Doctoral Thesis. University Kiel.

Kenward, M.G., Roger, J.H., 1997. Small sample inference for fixed effects from restricted maximum likelihood. Biometrics 53, 983 997.

Kuemmel, B., Langer, V., Magid, J., De Neergaard, A., Porter, J.R., 1998. Energetic, economic and ecological balances of a combined food and energy system. Biomass Bioenergy 15, 407-416.

Küsters, J., Lammel, J., 1999. Investigations of the energy efficiency of the production of winter wheat and sugar beet in Europe. Eur. J. Agron. 11, 35-43.

Littell, R.C., Milliken, G.A., Stroup, W.W., Wolfinger, R.D., 1996. SAS System for Mixed Models. SAS Institute Inc., Cary, NC.

McKyes, E.G., Owen, K.J., 1986. Energy analysis model of various tillage and fertilizer treatments on corn silage production. Can. Agric. Eng. 28, 101-105.

McLaughlin, N.B., Hiba, A., Wall, G.J., King, D.J., 2000. Comparison of energy inputs for inorganic fertilizer and manure based corn production. Can. J. Agric. Eng. 42, 2.1-2.14.

Monti, A., Venturi, G., 2003. Comparison of the energy performance of fibre sorghum, sweet sorghum and wheat monocultures in northern Italy. Eur. J. Agron. 19, 35-43.

O'Callaghan, J.R., 1994. Resource utilization and economy of soil tillage in crop production systems. Soil Till. Res. 30, 327-343.

Pervanchon, F., Bockstaller, C., Girardin, P., 2002. Assessement of energy use in arable farming systems by menas of an agroecological indicator: the energy indicator. Agric. Syst. 72, 149172.

Pimentel, D., 2003. Ethanol fuels: energy balance, economics, and environmental impacts are all negative. Nat. Resour. Res. 12, 127 134.

Pimentel, D., Hurd, L.E., Bellotti, A.C., Forster, M.J., Oka, I.N., Sholes, O.D., Whitman, R.J., 1973. Food production and the energy crisis. Science 182, 443-449.

Pimentel, D., Dazhong, W., Giampietro, M., 1990. Technological changes in US agricultural energy use. In: Gliessmann, S.R. (Ed.), Agroecology: Researching the Ecological Basis for Sustainable Agriculture. Springer, New York, pp. 305-321.

Rathke, G.-W., 1999. Auswirkung von Vorfrucht und Stickstoff (N)Düngung auf die Energiebilanz des Winterrapsanbaus. Cuvillier Verlag (Engl. summary).

Rathke, G.-W., Diepenbrock, W., 2006. Energy balance of winter oilseed rape (Brassica napus L.) cropping as related to nitrogen supply and previous crop. Eur. J. Agron. 24, 35-44.
Rathke, G.-W., Körschens, M., Diepenbrock, W., 2002. Substance and energy balances in the "static fertilisation experiments Bad Lauchstädt". Arch. Acker Pfl. Boden. 48, 423-433.

Reinhardt, G.A., 1993. Energie- und $\mathrm{CO}_{2}$-Bilanzierung Nachwachsender Rohstoffe. Vieweg Verlag Braunschweig/Wiesbaden.

Rosenberger, A., Kaul, H.P., Senn, T., Aufhammer, W., 2001. Improving the energy balance of bioethanol production from winter cereals: the effect of crop production intensity. Appl. Energy $68,51-67$.

Schiemann, R., 1981. Stoff- und energieansatz beim ausgewachsenen, vorwiegend fettbildenden tier. In: Gebhardt, B. (Ed.), Tierernährung. Deutscher Landwirtschaftsverlag, Berlin, pp. 131-160.

Smil, V., Nachman, P., Long II, T.V., 1983. Energy Analysis and Agriculture-An Application to U.S. Corn Production. Westview Press Inc.

Smith, J.A., Fornstorm, K.J., 1980. Energy requirements of selected dryland wheat cropping systems. Trans. ASAE 23, 822-825.

Stirling, B., 1976. Use of Non-renewable Energy on Saskatchewan Farms: A Preliminary Study. Saskatchewan Research Council, Province of Saskatchewan, Regina, Sask., 38 pp.

Strasil, Z., 1990. Energetická bilance osevních postupü s rüznou strukturou plodin. Rostlinná Výroba 36, 1-7 (Engl. summary).

Swanton, C.J., Murphy, S.D., Hume, D.J., Clements, D.R., 1996. Recent improvements in the energy efficiency of agriculture: case studies from Ontario, Canada. Agric. Syst. 52 (4.), 399-418.

Uri, N.D., 1999. The use of no till farming in US agriculture: farmers' perceptions versus reality. J. Sustainable Agric. 15 (2-3), 5-17.

Uri, N.D., 2000. Perceptions on the use of no-till farming in production agriculture in the United States: an analysis of survey results. Agric. Ecosyst. Env. 77 (3), 263-266.

Varvel, G.E., Wilhelm, W.W., 2003. Soybean nitrogen contribution to corn and sorghum in western corn belt rotations. Agron. J. 95, $1220-1225$.

Wang, M., Saricks, C., Wu, M., 1997. Fuel-cycle fossil energy use and greenhouse gas emissions of fuel ethanol produced from U.S. Midwest corn. Report Sponsored by the Illinois Department of Commerce and Community Affairs. Argonne National Laboratory, Center for Transportation Research, Argonne, IL 60439.

Wilhelm, W.W., Wortmann, C.S., 2004. Tillage and rotation interactions for corn and soybean grain yield as affected by precipitation and air temperature. Agron. J. 96, 425-432.

Woermann, E., 1944. Ernährungswirtschaftliche Leistungsmaßstäbe. Mitt. Landw. 59, 787-792.

Zentner, R.P., Campbell, D.W., Campbell, C.A., Read, D.W.L., 1984. Energy considerations of crop rotations in southwestern Saskatchewan. Can. J. Agric. Eng. 26, 25-29.

Zentner, R.P., Stumborg, M.A., Campbell, C.A., 1989. Effect of crop rotations and fertilization on energy balance in typical production systems on the Canadian prairies. Agric. Ecosyst. Env. 25, 217232.

Zentner, R.P., McConkey, B.G., Stumborg, M.A., Campbell, C.A., Selles, F., 1998. Energy performance of conservation tillage management for spring wheat production in the brown soil zone. Can. J. Plant Sci. 78, 553-563.

Zentner, R.P., Lafond, G.P., Derksen, D.A., Nagy, C.N., Wall, D.D., May, W.E., 2004. Effects of tillage method and crop rotation on non-renewable energy use efficiency for a thin black chernozem in the Canadian prairies. Soil Till. Res. 77, 125-136. 